\title{
Activation Product, Factor IX, Serum Thrombotic Accelerator Activity, and Serum-induced Thrombosis *
}

\author{
Daniel Deykin and Stanford Wessler \\ (From the Medical Research Department of the Yamins Research Laboratory, Beth Israel \\ Hospital, and the Department of Medicine, Harvard Medical School, Boston, Mass.)
}

Glass-contacted human serum infused into animals induces stasis thrombi similar to red thrombi observed in man (1). The activity in glass-contacted human serum initiating these thrombi has been termed serum thrombotic accelerator (STA) activity (2). It can be measured by a rabbit assay (3) and is distinct from tissue thromboplastin, platelets, and thrombin $(4,5)$. Silicone-processed ("intact") serum from normal subjects and glasscontacted serum from patients deficient in coagulation Factors XII (Hageman), XI (PTA), or IX (PTC) develop little, if any, STA activity (2, $5)$. In contrast, glass-contacted serum from patients with other clotting defects develops normal STA activity (2). These observations led to the hypothesis that elaboration of STA activity was mediated through activation of the initial three procoagulants (Factors XII, XI, and IX) involved in the in vitro formation of intrinsic, or blood, thromboplastin (1).

The role of Factor IX in the elaboration of STA activity has been recently brought under fresh scrutiny. Preparations rich in activated Factor XI (activation product, AP) and essentially devoid of other known clotting factors, have been found to be thrombogenic (6). This is true whether the AP is isolated from normal or Factor IX-deficient plasma or serum (6). As a result of these studies, it has been suggested that the thrombogenic activity originally described as STA activity is attributable to AP and that STA activity, in fact, represents the in vivo manifestation of AP (6).

To examine the validity of this thesis, the thrombogenic activity of serum obtained from patients with established heredofamilial defects of Factor

\footnotetext{
* Submitted for publication June 21, 1963; accepted October 3, 1963.

This study was supported by research grants H-1027 and HE-6316 from the National Institutes of Health and by a grant-in-aid from the American Heart Association.
}

IX was compared with that of serum from normal subjects by a standard bioassay, and these in vivo data were correlated with in vitro assays for AP and Factor IX. The experiments reported here demonstrate that although the elaboration of STA activity is dependent on the contact activation steps involved in the formation of intrinsic thromboplastin, STA activity cannot be equated with the activity measured by the one-stage partial thromboplastin assay of AP.

\section{Methods}

A. Collection of serum. Human serum was collected by venipuncture with a two-syringe technic, using silicone-coated ${ }^{1}$ syringes and monocoated ${ }^{2}$ needles. Blood to be assayed as "intact serum" was immediately transferred to silicone-coated tubes. Blood to be assayed as "contact serum" was immediately transferred to new, uncoated glass tubes before coagulation ensued. The processing of all blood samples was performed in tubes covered with parafilm. ${ }^{3}$ All serum samples were allowed to stand for 2 hours at room temperature and then for 18 hours at $4^{\circ} \mathrm{C}$. The blood samples were subsequently centrifuged for 20 minutes at $2,500 \times g$, and the serum removed. Several serum samples, collected initially as contact serum, were also exposed either to kaolin $(0.5$ $\mathrm{mg}$ per $\mathrm{ml}$ ) or Celite $4(30 \mathrm{mg}$ per $\mathrm{ml})$ for 10 minutes on an electric mixer at room temperature, and the powders were removed by centrifugation at $10,000 \times g$ at $4^{\circ} \mathrm{C}$ for 5 minutes and by subsequent filtration through Whatman 1 filter paper. All serum samples were stored in $3-\mathrm{ml}$ samples at $-20^{\circ} \mathrm{C}$. Subsequent manipulations were performed with siliconized equipment throughout. Individual tubes were defrosted only once, immediately before testing for in vivo and in vitro assays.

B. Thrombosis assay. Thrombus formation was measured by a standard rabbit assay (3) modified in that all manipulations, including the infusions, were performed by silicone technic. In addition, a second jugular vein was isolated, and the contents were examined for throm-

\footnotetext{
1 Siliclad, Clay-Adams, Inc., New York, N. Y.

2 Monocote-E, Armour Laboratories, Kankakee, Ill.

3 Parafilm M, Marathon Co., Menasha, Wis.

4 Dicalite Speedex, Great Lakes Carbon Co., Walteria, Calif.
} 
bus formation 15 minutes after isolation. The order of the serum infusions was determined by a series of random numbers, and the bioassay was performed by an individual unaware of the randomization sequence.

C. In vitro clotting tests. Exhausted plasma depleted of Factors XI and XII was prepared by a technic suggested by Schiffman and Rapaport (7). Nine volumes of whole blood was added to 1 vol of buffered $0.1 \mathrm{M}$ citrate (sodium citrate: citric acid, $3: 2$, vol/vol), and the plasma was then placed on a column of Celite $(1 \mathrm{~g}$ of Celite for each $\mathrm{ml}$ of plasma to be added) and subsequently eluted with $0.85 \%$. sodium chloride. As soon as the first traces of protein, assayed by the biuret reaction (8), appeared in the effluent, a fraction equal in volume to the starting plasma volume was collected. The effluent plasma was adjusted to $\mathrm{pH} 7.4$ and incubated at $37^{\circ} \mathrm{C}$ for 30 minutes. This plasma was next exposed to $5 \mathrm{mg}$ per $\mathrm{ml}$ of Celite on an electric mixer for 10 minutes, and the Celite was separated by centrifugation at $10,000 \times g$ for 10 minutes and then by filtration through Whatman 1 filter paper. This process of incubation and exposure to Celite was repeated until the blank time in the preformed AP assay (described below) reached 150 seconds. Clottingfactor activities remaining in plasma so treated were: Factor II (prothrombin), 70\% (9); Factor V (acglobulin), 50\% (10); Factor VII (convertin)-Factor $\mathrm{X}$ (Stuart) complex, $100 \%$ (9) ; Factor X, 70\% (11); and Factor VIII (antihemophilic factor), 96\% (12). Factor IX activity, measured by a modification of the technic of Wartelle (13) (see below) was $46 \%$ of normal intact plasma. When used as a plasma reagent in the thromboplastin generation test of Biggs and Douglas (14), this "exhausted" plasma supported normal thromboplastin generation.

AP-rich eluates were prepared from normal human plasma, according to the method of Henderson and Rapaport (6).

Preformed AP was assayed by a modification of the technic of Henderson and Rapaport (6). The test was performed by adding to a siliconized tube in order: $0.1 \mathrm{ml}$ of exhausted plasma, $0.1 \mathrm{ml}$ of a commercially prepared partial thromboplastin, ${ }^{5}$ and $0.1 \mathrm{ml}$ of the substance to be tested-all maintained at melting-ice temperature. The tube was then transferred to a water bath at $37^{\circ} \mathrm{C}$. After 30 seconds, $0.1 \mathrm{ml}$ of the $30 \mathrm{mM}$ calcium chloride solution was added and a stopwatch was simultaneously started. After 50 seconds, the tube was tilted gently every 5 seconds until a fibrin gel formed, at which moment the clotting time was recorded. Under conditions of glass-contact activation, individually processed samples of serum exhibited a wide range of preformed AP comparable to that described by other investigators (6).

A calibration curve (Figure 1) was prepared with a standard AP-rich eluate diluted serially with dilution fluid II of Waaler (15), to give an arbitrary reference standard for AP. With this system, it was possible to

5 Thrombofax reagent, Ortho Research Laboratory, Raritan, N. J., supplied through the courtesy of Dr. Heron Singher.

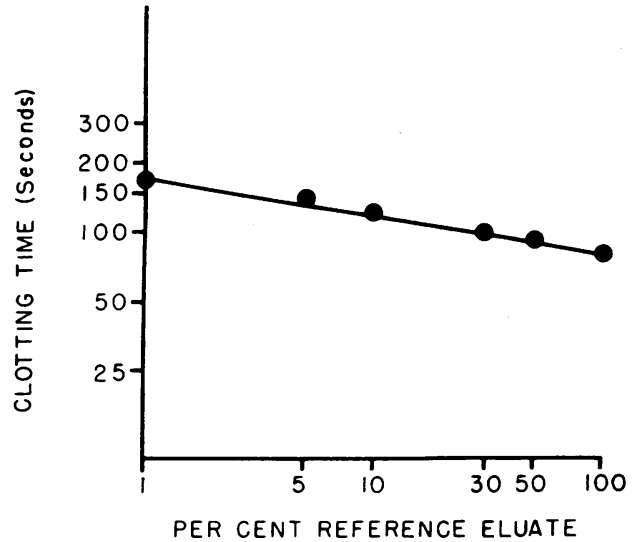

Fig. 1. The PREFormed activation-PROdUCt aCtivity OF A REFERENCE PLASMA ELUATE, RECONSTITUTED TO ORIGINAL PLASMa volume. $100 \%$ activity is defined by the clotting time (in seconds) of a system containing $0.1 \mathrm{ml}$ reference eluate, $0.1 \mathrm{ml}$ exhausted plasma, $0.1 \mathrm{ml}$ partial thromboplastin, and $0.1 \mathrm{ml} 30 \mathrm{mM} \mathrm{CaCl}$.

compare plasma, serum, and isolated blood fractions for AP activity, since the exhausted plasma supplied all known coagulation factors other than Factors XII and XI. To confirm that the exhausted plasma was in fact depleted of Factors XII and XI, normal, Factor XII-deficient, and Factor XI-deficient intact plasmas were assayed for AP before and after activation by kaolin powder (Table I).

Factor IX activity in serum was measured in a partial thromboplastin time assay that utilized as a substrate hen plasma, devoid of Factors XII, XI, and IX (13), and AP-rich eluates free of measurable quantities of all other procoagulants. To obtain such eluates for

TABLE I

The response of human plasma to kaolin activation

\begin{tabular}{c}
\hline \\
Plasma tested
\end{tabular}

A. Normal subjects

$\begin{array}{rrr}1 & 2 & 400 \\ 2 & 7 & 880 \\ 3 & 12 & 700 \\ 4 & 16 & 940 \\ 5 & 7 & 800 \\ 6 & 7 & 490 \\ 7 & 2 & 560 \\ 8 & 17 & 800\end{array}$

B. Factor XII-deficient subjects

$\begin{array}{lll}1 & 0 & 0 \\ 2 & 0 & 0\end{array}$

C. Factor XI-deficient subjects

$\begin{array}{lll}1 & 1 & 10 \\ 2 & 6 & 25\end{array}$

* Percentage of reference activity. 
use in this test, the AP eluates prepared as described above were adsorbed with barium sulfate, $6100 \mathrm{mg}$ per $\mathrm{ml}$ of eluate for 10 minutes on an electric mixer, to remove residual traces of Factors II, VII, IX, and X. This procedure, as noted by Waaler, also results in a marked loss of AP activity (15). The $10 \% \mathrm{AP}$ activity remaining, however, was sufficient to produce a linear dilution curve in the Factor IX assay (Figure 2). The test is performed (using dilution fluid II as diluent) by adding to a siliconized tube in order: $0.1 \mathrm{ml}$ of the test serum diluted $1: 5 ; 0.1 \mathrm{ml}$ of hen plasma collected on $3.8 \%$ sodium citrate, diluted $1: 2 ; 0.1 \mathrm{ml}$ of commercial partial thromboplastin (Thrombofax) diluted $1: 10$; and 0.1 $\mathrm{ml}$ of barium sulfate-adsorbed AP eluate. The reagents were added at melting-ice temperature. The tube was then transferred to a water bath at $37^{\circ} \mathrm{C}$, and after a

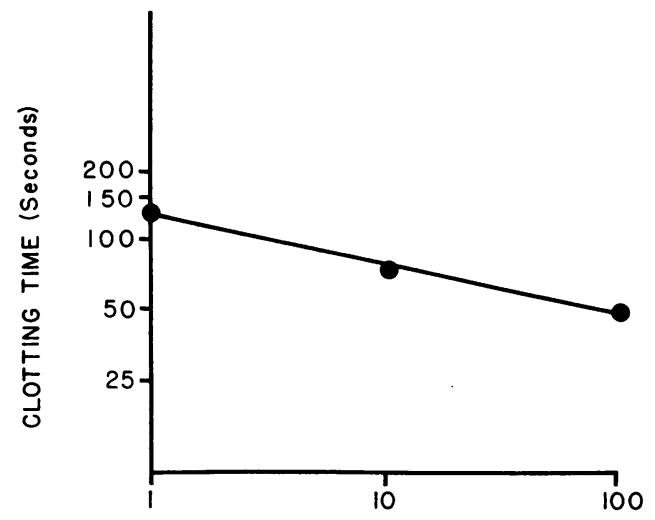

PER CENT SERUM FACTOR IX ACTIVITY

Fig. 2. Serum Factor IX ACtivity. 100\% activity is defined by the clotting time of the following system: 0.1 $\mathrm{ml}$ reference normal human serum $(1: 5), 0.1 \mathrm{ml}$ partial thromboplastin (1:10), $0.1 \mathrm{ml}$ hen plasma $(1: 2), 0.1 \mathrm{ml}$ $\mathrm{BaSO}_{4}$-adsorbed human activation product, and $0.1 \mathrm{ml}$ $30 \mathrm{mM} \mathrm{CaCl}{ }_{2}$. Dilution fluid II used for all dilutions.

30 -second incubation period, $0.1 \mathrm{ml}$ of $30 \mathrm{mM}$ calcium chloride was added and a stopwatch was started. The tube was allowed to stand for $\mathbf{3 0}$ seconds and then gently tilted every 5 seconds until a firm coagulum developed. Calibration curves (Figure 2) were prepared daily with a standard human serum, stored in samples at $-20^{\circ} \mathrm{C}$, by diluting this standard serum with dilution fluid II.

When normal human contact serum was assayed, sufficient AP was supplied by the test serum to make the addition of the AP eluates to the hen plasma unnecessary (Table II). For the calibration curves employing serial dilutions of normal glass-contacted human serum, however, the addition of AP-rich eluates was necessary to render the system critical only for Factor IX. Similarly, the addition of the AP eluate to the test system was necessary for the construction of calibration curves of intact plasma Factor IX activity to assess the Factor IX content of exhausted plasma (Table II). AP elu-

${ }^{6}$ J. T. Baker Chemical Co., Phillipsburg, N. J.
TABLE II

The influence of activation product, intact normal and Factor IX-deficient plasma, exhausted plasma, and contact normal human serum on the partial thromboplastin time of hen plasma

\begin{tabular}{lcc}
\hline \hline & \multicolumn{2}{c}{ Clotting time* } \\
\cline { 2 - 3 } & $\begin{array}{c}\text { Activation } \\
\text { product } \\
\text { added }\end{array}$ & $\begin{array}{c}\text { Activation } \\
\text { product } \\
\text { omitted }\end{array}$ \\
\hline Reagent blank $\ddagger$ & \multicolumn{3}{c}{ seconds } \\
Intact normal plasma & 157.9 & $>500$ \\
Intact Factor IX-deficient plasma & 110.5 & 231.7 \\
Exhausted plasma & 153.6 & 240.7 \\
Contact normal human serum & 117.9 & 226.8 \\
& 58.6 & 62.0
\end{tabular}

* Average of four determinations. Complete system as in Figure 2, with serum replaced by $1: 5$ dilutions of appropriate test plasma in dilution fluid II.

$\dagger \mathrm{BaSO}_{4}$ adsorbed activation product replaced by $0.1 \mathrm{ml}$ of $0.85 \% \mathrm{NaCl}$

$\ddagger$ Test plasma replaced by $0.1 \mathrm{ml}$ of dilution fluid II.

ates were routinely added to all Factor IX assays to insure that the Factor IX level would be independent of variations in the AP levels of the serum or plasma tested.

Thrombic activity was measured by the technic of Johnson and Seegers (16).

\section{Results}

The results of the infusions into rabbits of glasscontacted normal and Factor IX-deficient human serum and of the in vitro assays for AP and Factor IX are shown in Table III. Twenty-nine of 30 infusions of normal serum from three donors yielded full STA activity after 10 minutes of vein isolation, conforming with the expected results of the standard bioassay (3). In marked contrast, only 8 of 36 infusions of Factor IX-deficient serum were comparably thrombogenic. Six of these 8 bioassay score 4 thrombi $^{7}$ were induced by serum from Patient 4 , and 2 were from Patient 5; there were none from Patient 6 . Of the vein segments examined after 15 minutes of isolation, 30 of 30 infusions of normal, glass-contacted serum yielded full STA activity, whereas 12 of 36 infusions of glass-contacted Factor IX-deficient serum were comparably thrombogenic. Again, 8 of these 12 bioassay score 4 thrombi were induced by serum from Patient 4 , and 4 were from Patient 5 ; there were none from Patient 6.

\footnotetext{
${ }^{7}$ Bioassay score: $0=$ no thrombosis; $1=$ few macroscopic fibrin strands; $2=$ several small thrombi; $3=$ two or more large thrombi; $4=a$ single thrombus forming a cast of the isolated vein segment.
} 
TABLE III

Activation product, Factor IX, and serum thrombotic accelerator (STA) activity of glass-contacted human serum*

\begin{tabular}{|c|c|c|c|c|c|c|c|c|c|c|c|}
\hline \multirow{2}{*}{$\begin{array}{l}\text { Activation } \\
\text { product } \dagger\end{array}$} & \multirow[b]{2}{*}{ Factor IX† } & \multicolumn{2}{|c|}{ STA activity $\ddagger$} & \multirow{2}{*}{$\begin{array}{l}\text { Activation } \\
\text { product }\end{array}$} & \multirow[b]{2}{*}{ Factor IX } & \multicolumn{2}{|c|}{ STA activity } & \multirow{2}{*}{$\begin{array}{l}\text { Activation } \\
\text { product }\end{array}$} & \multirow[b]{2}{*}{ Factor IX } & \multicolumn{2}{|c|}{ STA activity } \\
\hline & & $10 \mathrm{~min}$ & $15 \mathrm{~min}$ & & & $10 \mathrm{~min}$ & $15 \mathrm{~min}$ & & & $10 \mathrm{~min}$ & $15 \mathrm{mi}$ \\
\hline \multicolumn{4}{|c|}{ Subject 1} & \multicolumn{4}{|c|}{ Subject 2} & \multicolumn{4}{|c|}{ Subject 3} \\
\hline $\begin{array}{r}1,000 \\
1,000 \\
1,000 \\
1,000 \\
860 \\
860 \\
760 \\
350 \\
250 \\
205\end{array}$ & $\begin{array}{r}180 \\
190 \\
100 \\
94 \\
160 \\
150 \\
120 \\
100 \\
90 \\
170\end{array}$ & $\begin{array}{l}4 \\
4 \\
4 \\
4 \\
4 \\
4 \\
4 \\
4 \\
4 \\
4\end{array}$ & $\begin{array}{l}4 \\
4 \\
4 \\
4 \\
4 \\
4 \\
4 \\
4 \\
4 \\
4\end{array}$ & $\begin{array}{l}1,000 \\
1,000 \\
1,000 \\
1,000 \\
1,000 \\
1,000 \\
1,000 \\
1,000 \\
1,000 \\
1,000\end{array}$ & $\begin{array}{r}220 \\
280 \\
130 \\
430 \\
96 \\
310 \\
360 \\
215 \\
215 \\
190\end{array}$ & $\begin{array}{l}4 \\
4 \\
4 \\
4 \\
4 \\
4 \\
4 \\
4 \\
4 \\
4\end{array}$ & $\begin{array}{l}4 \\
4 \\
4 \\
4 \\
4 \\
4 \\
4 \\
4 \\
4 \\
4\end{array}$ & $\begin{array}{l}460 \\
450 \\
445 \\
290 \\
270 \\
250 \\
195 \\
190 \\
135 \\
110\end{array}$ & $\begin{array}{r}68 \\
53 \\
52 \\
110 \\
86 \\
92 \\
56 \\
78 \\
95 \\
92\end{array}$ & $\begin{array}{l}4 \\
4 \\
4 \\
4 \\
4 \\
4 \\
4 \\
0 \\
4 \\
4\end{array}$ & $\begin{array}{l}4 \\
4 \\
4 \\
4 \\
4 \\
4 \\
4 \\
4 \\
4 \\
4 \\
4\end{array}$ \\
\hline \multicolumn{4}{|c|}{ Subject 4} & \multicolumn{4}{|c|}{ Subject 5} & \multicolumn{4}{|c|}{ Subject 6} \\
\hline $\begin{array}{r}100 \\
58 \\
53 \\
48 \\
45 \\
38 \\
38 \\
38 \\
36 \\
27 \\
18 \\
11\end{array}$ & $\begin{array}{l}1 \\
1 \\
1 \\
1 \\
1 \\
1 \\
1 \\
1 \\
1 \\
1 \\
1 \\
1\end{array}$ & $\begin{array}{l}4 \\
2 \\
4 \\
4 \\
4 \\
4 \\
0 \\
0 \\
0 \\
0 \\
0 \\
4\end{array}$ & $\begin{array}{l}4 \\
0 \\
4 \\
4 \\
4 \\
4 \\
4 \\
0 \\
2 \\
0 \\
4 \\
4\end{array}$ & $\begin{array}{r}1,000 \\
1,000 \\
1,000 \\
980 \\
780 \\
450 \\
140 \\
74 \\
72 \\
70 \\
58 \\
57\end{array}$ & $\begin{array}{r}18 \\
13 \\
15 \\
10 \\
7 \\
12 \\
13 \\
11 \\
11 \\
14 \\
13 \\
10\end{array}$ & $\begin{array}{l}0 \\
0 \\
4 \\
0 \\
0 \\
0 \\
0 \\
1 \\
0 \\
4 \\
0 \\
1\end{array}$ & $\begin{array}{l}0 \\
0 \\
4 \\
1 \\
0 \\
0 \\
4 \\
4 \\
0 \\
4 \\
0 \\
0\end{array}$ & $\begin{array}{r}450 \\
200 \\
200 \\
195 \\
170 \\
135 \\
135 \\
130 \\
100 \\
100 \\
100 \\
45\end{array}$ & $\begin{array}{l}0 \\
0 \\
0 \\
0 \\
0 \\
0 \\
0 \\
0 \\
0 \\
0 \\
0 \\
0\end{array}$ & $\begin{array}{l}0 \\
0 \\
0 \\
0 \\
0 \\
0 \\
0 \\
0 \\
0 \\
0 \\
0 \\
0\end{array}$ & $\begin{array}{l}0 \\
0 \\
0 \\
0 \\
0 \\
0 \\
0 \\
0 \\
0 \\
0 \\
0 \\
0\end{array}$ \\
\hline
\end{tabular}

* Sera from Subjects 1 and 4, 2 and 5, 3 and 6 were processed simultaneously. Values listed in decreasing order of activation product levels.

$\dagger$ Percentage of reference activity.

† Bioassay score: $0=$ no thrombosis; 1 = few macroscopic fibrin strands; $2=$ several small thrombi; $3=$ two or more large thrombi; $4=\mathrm{a}$ single thrombus forming a cast of the isolated vein segment.

There was a striking variation in the AP content among individual tubes of normal serum. As noted above (see Methods) this is the anticipated range by the technic employed. This variation is not caused by thrombin contamination $(17)$; in the assay for thrombic activity, no fibrin gel formation was noted during the 5 -minute period in which each tube was observed. It is apparent that almost all the AP values for serum from Patients 5 and 6 were within the range of those for serum from the three normal subjects (Subjects 1, 2, and 3), yet serum from Patient 6 was entirely nonthrombogenic, and serum from Patient 5 was only minimally thrombogenic. Paradoxically, serum

TABLE IV

Activation product and serum thrombotic accelerator (STA) activity of activated human serum

\begin{tabular}{|c|c|c|c|c|c|c|c|c|c|c|c|c|}
\hline & \multirow[b]{3}{*}{ No. of assays } & \multirow[b]{3}{*}{ Activation product* } & \multicolumn{10}{|c|}{ STA activity† } \\
\hline & & & \multicolumn{5}{|c|}{ 10-minute stasis } & \multicolumn{5}{|c|}{ 15-minute stasis } \\
\hline & & & 0 & 1 & 2 & 3 & 4 & 0 & 1 & 2 & 3 & 4 \\
\hline \multicolumn{13}{|l|}{ Kaolin activated } \\
\hline $\begin{array}{l}\text { Normal serum Patient 3, Table III } \\
\text { Factor IX-deficient Patient 5, Table III }\end{array}$ & $\begin{array}{l}3 \\
3\end{array}$ & $\begin{array}{l}1,000 \ddagger \\
1,000 \ddagger\end{array}$ & $\begin{array}{l}0 \\
2\end{array}$ & $\begin{array}{l}0 \\
0\end{array}$ & $\begin{array}{l}\mathbf{0} \\
\mathbf{0}\end{array}$ & $\begin{array}{l}\mathbf{0} \\
\mathbf{0}\end{array}$ & $\begin{array}{l}3 \\
1\end{array}$ & $\begin{array}{l}\mathbf{0} \\
\mathbf{0}\end{array}$ & $\begin{array}{l}\mathbf{0} \\
\mathbf{0}\end{array}$ & $\begin{array}{l}0 \\
0\end{array}$ & $\begin{array}{l}0 \\
0\end{array}$ & $\begin{array}{r}3 \\
3\end{array}$ \\
\hline \multicolumn{13}{|l|}{ Celite activated } \\
\hline $\begin{array}{l}\text { Normal serum Patient 3, Table III } \\
\text { Factor IX-deficient Patient 5, Table III }\end{array}$ & $\begin{array}{l}2 \\
3\end{array}$ & $\begin{array}{l}1,000 \ddagger \\
1,000 \ddagger\end{array}$ & $\begin{array}{l}0 \\
2\end{array}$ & $\begin{array}{l}0 \\
1\end{array}$ & $\begin{array}{l}\mathbf{0} \\
\mathbf{0}\end{array}$ & $\begin{array}{l}\mathbf{0} \\
\mathbf{0}\end{array}$ & $\begin{array}{l}2 \\
0\end{array}$ & $\begin{array}{l}\mathbf{0} \\
\mathbf{0}\end{array}$ & $\begin{array}{l}\mathbf{0} \\
\mathbf{0}\end{array}$ & $\begin{array}{l}\mathbf{0} \\
\mathbf{0}\end{array}$ & $\begin{array}{l}0 \\
1\end{array}$ & $\begin{array}{l}2 \\
2\end{array}$ \\
\hline
\end{tabular}

* Percentage of reference activity.

$\dagger$ Bioassay score as in Table III.

$\ddagger$ All values in excess of $1,000 \%$ 
TABLE V

Activation product and serum thrombotic accelerator (STA) activity of intact human serum

\begin{tabular}{|c|c|c|c|c|c|c|c|c|c|c|c|}
\hline & \multirow[b]{3}{*}{ No. of assays } & \multirow{3}{*}{$\begin{array}{l}\text { Activation product* } \\
\text { mean and range }\end{array}$} & \multicolumn{9}{|c|}{ STA activity $†$} \\
\hline & & & \multicolumn{5}{|c|}{ 10-minute stasis } & \multicolumn{4}{|c|}{ 15-minute stasis } \\
\hline & & & 0 & 1 & 2 & 3 & 4 & 0 & 1 & 2 & 3 \\
\hline Normal subject Patient 3, Table III & 4 & $\begin{array}{c}14 \\
(10-20)\end{array}$ & 4 & 0 & 0 & 0 & 0 & 3 & 0 & 1 & 0 \\
\hline $\begin{array}{l}\text { Factor IX-deficient subject Patient 6, } \\
\text { Table III }\end{array}$ & 4 & $\begin{array}{c}12 \\
(11-13)\end{array}$ & 4 & 0 & 0 & 0 & 0 & 4 & 0 & 0 & 0 \\
\hline
\end{tabular}

* Percentage of reference activity.

† Bioassay score as in Table III.

from Patient 4, whose AP values were almost all below the normal range, was clearly the most thrombogenic of the three Factor IX-deficient sera tested. Although the serum from Patient 4 may be atypical (see Discussion), it is apparent from the data in Table III that the AP level of glass-contacted serum is not an in vitro measure of STA activity. The validity of this conclusion is supported by supplemental experiments in which AP levels and STA activity of normal and Factor IXdeficient serum were determined after exposure of the serum to kaolin or Celite. Although both normal and Factor IX-deficient serum reached equally elevated levels of AP, normal serum, after 10 minutes of vein isolation, was still more thrombogenic than Factor IX-deficient serum (Table IV). After 15 minutes this difference was no longer apparent.

It is also clear that STA activity cannot be elaborated without prior activation of Factor XI. Thus, intact serum prepared from normal subjects or Factor IX-deficient patients elaborated negligible amounts of AP and induced no thrombosis after 10 minutes of stasis (Table V).

\section{Discussion}

This study was undertaken to determine whether or not STA activity is the in vivo manifestation of AP.

Waaler has shown that the measurement of AP by a one-stage, partial thromboplastin assay reflects contact activation and detects hereditary deficiencies in Factor XII or XI (15). In addition, he has demonstrated that glass-contacted serum, although rich in AP, elaborates a strikingly higher AP titer after exposure of such serum to sub- stances that provide additional surface area for activation (15).

The data presented in Table III demonstrate, however, that when serum is exposed to a partially activating surface, such as new, uncoated glass tubes, or even exposed to kaolin or Celite (Table IV), the thrombogenic capacity of serum does not correlate with the AP content.

It is true that in the absence of any contact activation, serum infusates are not thrombogenic and are essentially devoid of AP (Table V). Conversely, under the extreme conditions of activation that follow exposure to diatomaceous earths, coupled with 15 minutes of stasis, normal and Factor IX-deficient serum infusates are equally thrombogenic and contain comparably large amounts of AP (Table IV). These observations indicate that contact activation is required for serum to elaborate thrombogenic activity and are consistent with the view that $\mathrm{AP}$ itself in sufficient titer is a thrombogenic moiety. These observations do not of themselves, however, permit the conclusion that the thrombogenic activity of partially activated serum is due entirely to its AP content.

Studies of the kinetics of the sequential steps of the clotting of blood in vitro have made it abundantly clear that the various reactions occur at profoundly different rates, that the principal ratelimiting steps occur early in the coagulation sequence, and that these initial reactions may be accelerated by the exposure of blood to increased surface areas. A high concentration of infused AP may by itself so accelerate coagulation in isolated venous segments as to obscure the role of infused activated Factor IX in thrombogenesis. It appears, however, that under conditions of partial 
activation of serum (i.e., glass-contacted), the presence of Factor IX influences a rate-limiting step critical for the induction of thrombosis.

No evidence has indicated that the measurement of AP reflects all the activities encompassed by the process of contact activation. It is possible that intermediary reactions, not yet defined by genetic abnormalities or biochemical analysis, participate in contact activation. In fact, the vigorous treatment of plasma required to prepare a plasma substrate devoid of Factors XII and XI, yet retaining adequate quantities of the remaining recognized procoagulants, may deplete the plasma of other activities involved in the contact process. If this thesis is valid, the measurement of AP might not detect a critical reaction in the activation process that could contribute significantly to thrombogenesis.

It has been suggested that Factor IX assayed in plasma and in serum represents different activities. Serum Factor IX activity may reflect the conversion of an inactive plasma precursor to an active procoagulant (18-20). Quick has indicated that congenital Factor IX deficiency may in fact represent the inability to convert inert plasma Factor IX to an active form (21). Duckert has described an activity, prephase accelerator or PPA, that yields Factor IX activity in one-stage clotting assays, but which can be distinguished from "genuine" Factor IX activity, as measured in serum in the thromboplastin generation test (22). Whether, therefore, the conversion of plasma Factor IX to serum Factor IX activity gives rise to a specific moiety that is itself thrombogenic remains to be determined.

Several investigators have demonstrated inhibitors to Factor IX activity in vitro $(23,24)$. The serum from Factor IX-deficient Patient 4 (Table III) evolved little AP activity after exposure to glass, in contrast to serum from Factor IX-deficient Patients 5 and 6 (Table III). More than $50 \%$ of the serum samples obtained from Patient 4, however, were thrombogenic. This patient, in contrast to Patients 5 and 6 , had received multiple transfusions of normal human plasma during the 3 months immediately preceding the present study. It is possible that the disparity between his low AP values and high STA activity reflected a complex reaction to previously infused normal plasma.
The data on Patients 5 and 6 (Table III) do show some AP values below the normal range. These discrepancies may derive from the presence in normal serum of activated Factor IX causing an enhanced acceleration of the AP assay and thus a higher apparent AP level in normal serum than in Factor IX-deficient serum. Such an interpretation, although it raises doubts concerning the specificity of the AP assay in serum, only strengthens the thesis that activated Factor XI cannot be equated with STA activity.

Evidence has been recently summarized to support the view that activation of one or more of the initial procoagulants may lead to the formation of fibrin thrombi in areas of retarded blood flow in man (1). The contribution of stasis to the genesis of these thrombi may be interpreted as the development of an altered physiologic state wherein the activated products of coagulation are protected by a mechanism such as removal of clotting intermediates from the circulation, as suggested by Spaet and Kropatkin $(25,26)$. In terms of this concept, the initiation of the stasis thrombus depends on the acceleration of intravascular coagulation to a rate that exceeds the capacity of the compensatory clearance mechanism. The experiments reported in this communication suggest that when human serum is infused, activation of Factor IX or some associated moiety in the infusate may govern a rate-limiting step that determines whether or not stasis thrombi will form.

\section{Summary}

1) The thrombogenicity of infusions of glasscontacted normal and Factor IX-deficient human serum in rabbits and the activation product (AP) and Factor IX content of these infusates were determined.

2) Glass-contacted Factor IX-deficient serum was markedly less thrombogenic than normal human serum. The thrombogenicity of glass contacted Factor IX-deficient serum did not correlate with its level of AP.

3) Although elaboration of serum thrombotic accelerator (STA) activity is dependent on the contact activation steps involved in the formation of intrinsic thromboplastin, STA activity cannot be equated with the activity measured by the one-stage partial thromboplastin assay of AP. Thus, STA activity is not the in vivo manifestation of AP. 
4) Factor IX, or an associated moiety in serum, plays a critical role in the formation of stasis thrombi induced by infusions of human serum.

\section{Acknowledgments}

The authors gratefully acknowledge the valuable technical assistance of Victoria J. Ream and Sandra Svihovec. We are indebted to Drs. Louis K. Diamond and Herbert S. Strauss of the Children's Hospital and Harvard Medical School, Boston, Mass., for generously providing us with serum from a patient deficient in Factor IX.

\section{References}

1. Wessler, S. Thrombosis in the presence of vascular stasis. Amer. J. Med. 1962, 33, 648.

2. Wessler, S., and S. M. Reimer. The role of human coagulation factors in serum-induced thrombosis. J. clin. Invest. 1960, 39, 262.

3. Wessler, S., S. M. Reimer, and M. C. Sheps. Biologic assay of a thrombosis-inducing activity in human serum. J. appl. Physiol. 1959, 14, 943.

4. Wessler, S. Studies in intravascular coagulation. III. The pathogenesis of serum-induced venous thrombosis. J. clin. Invest. 1955, 34, 647.

5. Wessler, S., S. M. Reimer, D. G. Freiman, and D. P. Thomas. Factors involved in the initiation of thrombosis in Anticoagulants and Fibrinolysins, R. L. MacMillan and J. F. Mustard, Eds. Toronto, Macmillan, 1961, p. 108.

6. Henderson, E. S., and S. I. Rapaport. The thrombotic activity of activation product. J. clin. Invest. 1962, 41, 235.

7. Schiffman, S., and S. I. Rapaport. Personal communication.

8. Gornall, A. G., C. S. Bardawill, and M. M. David. Determination of serum proteins by means of the biuret reaction. J. biol. Chem. 1949, 177, 751.

9. Owren, P. A., and K. Aas. The control of dicumarol therapy and the quantitative determination of prothrombin and proconvertin. Scand. J. clin. Lab. Invest. 1951, 3, 201.

10. Owren, P. A. New clotting factors in Transactions of the Fifth Conference on Blood Clotting and Allied Problems, J. E. Flynn, Ed. New York, Josiah Macy, Jr. Foundation, 1952, p. 98.

11. Bachmann, F., F. Duckert, and F. Koller. The Stuart-Prower factor assay and its clinical significance. Thrombos. Diathes. haemorrh. (Stuttg.) 1958, 2, 24.
12. Hardisty, R. M., and J. C. Macpherson. A one-stage factor VIII (antihaemophilic globulin) assay and its use on venous and capillary plasma. Thrombos. Diathes. haemorrh. (Stuttg.) 1962, 7, 215.

13. Wartelle, $O$. Travail du centre national de transfusion sanguine. Thesis, Paris, 1959.

14. Biggs, R., and A. S. Douglas. The thromboplastin generation test. J. clin. path. 1953, 6, 23.

15. Waaler, B. A. Contact activation in the intrinsic blood clotting system. Scand. J. clin. Lab. Invest. 1959,11 , suppl. 37.

16. Johnson, J. F., and W. H. Seegers. Preparation, purification and assay of thrombin in The Coagulation of Blood: Methods of Study. New York, Grune \& Stratton, 1955, p. 120.

17. Rapaport, S. I., S. Schiffman, M. J. Patch, and S. B. Ames. The importance of activation of antihemophilic globulin and proaccelerin by traces of thrombin in the generation of intrinsic prothrombinase activity. Blood 1963, 21, 221.

18. Lewis, F. J. W., and F. Nour-Eldin. Factor IX in intravascular and extravascular blood coagulation. Blood 1962, 20, 41.

19. Ratnoff, O. D., and E. W. Davie. The activation of Christmas factor (factor IX) by activated plasma thromboplastin antecedent (activated factor XI). Biochemistry 1962, 1, 677.

20. Schiffman, S., S. I. Rapaport, and M. J. Patch. PTC' (activated factor IX): an important intermediate in intrinsic clotting. Clin. Res. 1963, 11, 104

21. Quick, A. J. The hereditary haemorrhagic diseases: their classification and diagnosis. Brit. med. J. 1959, 1, 1059.

22. Duckert, F. The prephase accelerator. Present status. Thrombos. Diathes. haemorrh. (Stuttg.) 1961, 6, 254.

23. Mustard, J. F. The serum defect in Christmas disease. Acta haemat. (Basel) 1959, 21, 321.

24. Hardisty, R. M. A naturally occurring inhibitor of Christmas factor (factor IX). Thrombos. Diathes. haemorrh. (Stuttg.) 1962, 8, 67.

25. Spaet, T. H., and M. Kropatkin. Effect of intravenous soy bean phosphatides on blood coagulation in rabbits. Proc. Soc. exp. Biol. (N. Y.) 1957, 95, 492.

26. Spaet, T. H. Studies on the in vivo behavior of blood coagulation product $I$ in rats. Thrombos. Diathes. haemorrh. (Stuttg.) 1962, 8, 276. 